\title{
Pembelajaran Jarak Jauh Selama Pandemi di Pondok Pesantren Darunajah 2 Bogor
}

\author{
Nur Hayati ${ }^{1}$ \\ Universitas Terbuka
}

\begin{abstract}
In an effort to suppress the spread of the Covid-19 virus, Kemdikbud took a policy to close schools during the Covid-19 pandemic. All schools that initially did conventional learning by face-to-face, now learning is done from home through distance learning or online system, no exception pondok pesantren. The purpose of this research is to find out the distance learning process conducted by Pondok Pesantren Darunnajah 2 Cipining, Bogor. This research was conducted using descriptive qualitative approach. Based on research can be known that in learning, pesantren use various platforms such as google classroom, google meet, whatsapp, and smart system. In this online learning, the materials and tasks given are quite diverse, although there are no tasks in the form of discussions so that the interaction between students and students and teachers cannot be done. All parties, both students, teachers, and parents experienced a culture shock with the existence of this distance learning system / online. Distance learning /online also gives rise to physical distancing. Religious activities that are usually carried out in pesantren are now carried out at home and all must be reported to the teacher or room guardian via whatsapp. The challenges faced in online learning include a lack of interaction between teachers and students, a network that arises to sink, quotas that are rapidly depleted and expensive, and a lack of active participation of students. Therefore, the readiness of both teachers and students, as well as motivation from parents can also support the implementation of this distance learning process. In addition, the provision of quotas is also important to support the online learning process carried out by pesantren.
\end{abstract}

Keywords: Covid-19 Pandemic, Distance Learning, Boarding Schools

\begin{abstract}
Abstrak
Sebagai upaya untuk menekan penyebaran virus Covid-19, Kemdikbud mengambil kebijakan untuk menutup sekolah selama masa pandemi Covid-19. Semua sekolah yang awalnya melakukan pembelajaran secara konvensional dengan tatap muka, kini pembelajaran dilakukan dari rumah melalui pembelajaran jarak jauh atau system daring (online), tidak terkecuali pondok pesantren. Tujuan penelitian ini adalah untuk mengetahui proses pembelajaran jarak jauh yang dilakukan oleh Pondok Pesantren Darunnajah 2 Cipining, Bogor. Penelitian ini dilakukan menggunakan pendekatan kualitatif deskriptif. Berdasarkan penelitian dapat diketahui bahwa dalam pembelajaran, pesantren menggunakan berbagai platform seperti google classroom, google meet, whatsapp, dan smart system. Dalam pembelajaran daring ini, materi dan tugas yang diberikan cukup beragam, meskipun tidak ada tugas dalam bentuk diskusi sehingga interaksi antara santri dengan santri maupun santri dengan guru tidak dapat dilakukan. Semua pihak, baik santri, guru, maupun orang tua mengalami gegar budaya (culture shock) dengan adanya sistem pembelajaran jarak jauh/daring ini. Pembelajaran jarak jauh/daring juga memunculkan adanya menjaga jarak fisik (physical distancing). Kegiatan keagamaan yang biasanya dilakukan di pesantren pun kini dilakukan di rumah dan semuanya harus dilaporkan kepada guru atau wali kamar melalui whatsapp. Tantangan yang dihadapi dalam pembelajaran daring ini antara lain kurangnya interaksi antara guru dan santri, jaringan yang timbul tenggelam, kuota yang cepat habis dan mahal, dan kurangnya partisipasi aktif santri. Oleh karena itu, diperlukan kesiapan baik guru dan santri, serta motivasi dari orang tua juga dapat mendukung terlaksananya proses pembelajaran jarak jauh ini. Selain itu, pemberian kuota juga menjadi hal yang penting untuk mendukung proses pembelajaran daring yang dilakukan pesantren.
\end{abstract}

Kata Kunci: Pandemi Covid-19, Pembelajaran Jarak Jauh, Pondok Pesantren

\footnotetext{
${ }^{1}$ nurhayati1@ecampus.ut.ac.id
} 


\section{Pendahuluan}

Akhir tahun 2019, yaitu 31 Desember 2019, WHO China Country Office melaporkan kasus pneumonia yang tidak diketahui etiologinya di Kota Wuhan, Provinsi Hubei, China. Kemudian pada 7 Januari 2020, China mengidentifikasi pneumonia yang tidak diketahui etiologinya tersebut sebagai jenis baru coronavirus (novel coronavirus, 2019-nCoV). Virus jenis baru ini sebelumnya belum pernah diidentifikasi pada manusia. Penyebaran virus corona ini berlangsung begitu cepat sehingga tiap harinya pun penderita bertambah, bahkan penyebaranya pun tidak hanya di Wuhan saja, tetapi mulai memasuki negara lain, termasuk Indonesia. Kasus virus corona masuk ke Indonesia terdeteksi dari dua WNI, yaitu seorang ibu (64 tahun) dan putrinya (31 tahun). Keduanya diduga tertular virus corona dari kontak langsung dengan warga negara Jepang yang datang ke Indonesia. Kasus Covid-19 pertama kali di Indonesia ini di sampaikan oleh Presiden Jokowi pada 2 Maret 2020. WHO mencatat bahwa hingga 29 Juli 2020, virus corona ini sudah menyebar ke 216 negara dengan kasus terkonfirmasi sebanyak 16.341 .920 orang dan meninggal 650.805 orang. Sementara itu, kasus di Indonesia, positif menjadi 102.051 orang, sembuh 60.539 orang, dan meninggal 4.901 orang (https://covid19.go.id/Juli 2020).

Kasus penyebaran virus corona ini tentunya sangat menggangu segala aspek kehidupan, termasuk dalam bidang pendidikan. Bahkan berdasarkan data UNESCO, lebih dari $91 \%$ populasi siswa dunia telah dipengaruhi oleh penutupan sekolah karena pandemi Covid-19 (Dirjen GTK, 2020). Kegiatan belajar mengajar di sekolah menjadi terganggu sehingga pemerintah melalui Kemdikbud telah mengambil kebijakan untuk menutup sekolah selama masa pandemi Covid-19. Kegiatan belajar mengajar pun dialihkan melalui penyelenggaraan pembelajaran jarak jauh (PJJ), sesuai dengan Surat Edaran Sekretaris Jenderal Kementerian Pendidikan dan Kebudayaan Nomor 15 Tahun 2020 tentang Pedoman Penyelenggaraan Belajar dari Rumah dalam Masa Darurat Penyebaran Coronavirus Disease (Covid-19). Kebijakan ini dilakukan sebagai upaya untuk mencegah penyebaran dan penularan virus Corona Covid-19 di lingkungan satuan pendidikan. Selain itu, Kementerian Pendidikan dan Kebudayaan (Kemendikbud) juga mengelurakanSurat Edaran Mendikbud Nomor 4 Tahun 2020 berisi arahan mengenai belajar dari rumah melalui pembelajaran jarak jauh dengan rincian sebagai berikut (1) memberikan pengalaman belajar yang bermakna bagi siswa, tanpa terbebani tuntutan menuntaskan seluruh capaian kurikulum kenaikan kelas maupun kelulusan (2) memfokuskan pada pendidikan kecakapan hidup antara lain mengenai pandemi Covid-19 (3) Memberikan variasi aktivitas dan tugas pembelajaran belajar dari rumah antarsiswa, sesuai minat dan kondisi masing-masing, termasuk mempertimbangkan kesenjangan akses/fasilitas belajar dari rumah. (Kemdikbud, 2020).

Pembelajaran jarak jauh (PJJ) merupakan sistem pembelajaran yang tidak berlangsung dalam suatu ruangan kelas sehingga tidak ada interaksi langsung secara tatap muka antara pengajar dan pembelajarnya (Munir, 2012). Pembelajaran jarak jauh (distance learning) merupakan pelatihan yang diberikan kepada peserta atau siswa yang tidak berkumpul bersama di satu tempat secara rutin untuk menerima pelajaran secara langsung dari instruktur. Bahan-bahan dan instruksi-instruksi detail yang 
bersifat khusus dikirimkan atau disediakan untuk para peserta yang selanjutnya melaksanakan tugastugas yang akan dievaluasi oleh instruktur. Dalam kenyataannya dapat dimungkinkan instruktur dan peserta tersebut terpisah tidak hanya secara geografis namun juga waktu (ica-sae.org). Dalam pembelajaran jarak jauh ini, interaksi antara pendidik dan siswa dilakukan menggunakan media teknologi dan komunikasi. Melalui teknologi dan komunikasi, interaksi antara pendidik dan siswa dapat dilakukan dengan bentuk waktu nyata (real time) dan waktu tidak nyata (a real time) (Munir, 2012). Pembelajaran jarak jauh menggunakan waktu nyata (real time/synchronous) dapat melalui daring zoom, googlemeet, webex, dan sebagainya. Sedangkan untuk pembelajaran menggunakan waktu tidak nyata (a real time/asynchronous) dapat melalui e-learning seperti moodle, google classroom, edmodo, schoology, dan sebagainya. Pembelajaran jarak jauh merupakan pembelajaran yang sudah ada sejak abad ke-18 (Belawati, 2019). Di Indonesia pun sebenarnya, model pembelajaran jarak jauh ini sudah tidak asing lagi karena di berbagai universitas/pendidikan tinggi sudah dilakukan, seperti di Univsersitas Terbuka.

Pondok Pesantren Darunnajah 2 Bogor merupakan pesantren modern atau sekolah berasrama (boarding school) yang kurikulumnya perpaduan antara kurikulum pondok modern Darussalam Gontor, kurikulum Nasional, dan juga Salaf. Di pesantren ini, siswa atau santri tidak hanya dibekali ilmu agama, tetapi juga dibekali oleh ilmu pengetahuan umum di sekolah. Sejak diberlakukannya surat edaran dari Kemdikbud, sekolah-sekolah, baik negeri maupun swasta melakukan pembelajaran jarak jauh, tak terkecuali pondok pesantren. Semenjak adanya Surat Edaran tersebut, Pesantren Darunnajah 2 Bogor langsung memulangkan santrinya dan mulai memberlakukan sistem pembelajaran jarak jauh. Sistem pembelajaran jarak jauh yang dilakukan oleh pesantren ini melalui strategi pembelajaran online. Menurut Moore, Dickson-Deane, \& Galyen (2011), pembelajaran online merupakan pembelajaran yang menggunakan jaringan internet dengan aksesibilitas, konektivitas, fleksibilitas, dan kemampuan untuk memunculkan berbagai jenis interaksi pembelajaran. Penggunaan teknologi memiliki kontribusi besar dalam dunia pendidikan, termasuk di dalamnya pencapaian tujuan pembelajaran jarak jauh (Korucu \& Alkan, 2011). Oleh karena itu, dalam pembelajaran online diperlukan perangkat-perangkat mobile, seperti laptop, tablet, dan telepon pintar (smartphone) untuk mengakses materi yang disampaikan guru. Lalu, bagimana proses pembelajaran jarak jauh yang dilaksakan oleh Pondok Pesantren Darunnajah 2 Cipining, Bogor? Bagaimana interaksi antara guru dan santri? Bagaimana bentuk dukungan guru dan orang tua kepada santri? Untuk mengetahui hal-hal tersebut, proses pembelajaran jarak jauh yang dilakukan oleh Pondok Pesantren Darunnajah 2 Bogor ini menarik untuk dikaji.

\section{Metode Penelitian}

Penelitian yang berjudul "Pembelajaran Jarak Jauh selama Pandemi di Pondok Pesantren Darunnajah 2 Bogor" ini menggunakan metode penelitian kualitatif. Penelitian ini untuk menggali, memahami, dan menggambarkan suatu objek penelitian dengan cara deskriptif berupa kata-kata dan 
bahasa (Moleong, 2011). Penelitian ini untuk mendeskripsikan tentang proses pembelajaran jarak jauh yang diterapkan oleh Pondok Pesantren Darunnajah 2 Bogor, mengetahui interaksi antara guru dan santri selama pembelajaran jarak jauh, dan bentuk dukungan guru dan orang tua kepada santri. Teknik pengumpulan data dalam penelitian ini menggunakan wawancara. Penulis melakukan wawancara kepada lima guru, sepuluh santri yang terdiri dari santri MTS dan MA, dan tiga orang wali santri/orang tua. Pengambilan data menggunakan wawancara kepada semua guru, santri, dan wali santri Pondok Pesantren Darunnajah 2 Bogor melalui whatsapp dan telepon. Analisis data penelitian dilakukan menggunakan model analisis Miles \& Huberman (Sugiyono, 2011) yang terdiri dari tiga tahapan, yaitu reduksi data, display data, serta penarikan dan verifikasi kesimpulan.

\section{Hasil dan Pembahasan}

\section{Kegiatan Pembelajaran Jarak Jauh di Pondok Pesantren Darunnajah 2 Bogor}

Pondok Pesantren Darunnajah 2 Bogor merupakan pondok pesantren modern yang kurikulumnya tingkat Tarbiyatul Mu'allimin wa al-Mu'allimat al Islamiyah adalah perpaduan kurikulum Pondok Modern Darussalam Gontor dan kurikulum Nasional serta Pesantren Salafiah. Dengan demikian dapat dikatakan bahwa pembelajarannya pun ilmu keagamaaan dan umum. Sistem pengajaran yang dipakai adalah klasikal dengan metode yang mendorong keaktifan siswa dalam belajar dan dengan terus mengikuti perkembangan di bidang teori kependidikan/metodologi pengajaran. Sebagai upaya memutus mata rantai penyebaran Covid-19, Pondok Pesantren Darunnajah 2 Bogor mulai Maret 2020 melaksanakan pembelajaran jarak jauh menggunakan sistem daring (online). Pembelajaran daring (online) merupakan bagian dari pembelajaran jarak jauh atau dapat dikatakan bahwa pembelajaran daring pada dasarnya merupakan pembelajaran jarak jauh. Istilah online learning banyak disinonimkan dengan istilah lainnya seperti e-learning, internet learning, webbased learning, tele-learning, dis-tributed learning, dan sebagainya (Belawati, 2019). Adapun menurut Menurut Moore, Dickson-Deane, \& Galyen (2011), pembelajaran daring (online) adalah pembelajaran yang menggunakan jaringan internet dengan aksesibilitas, konektivitas, fleksibilitas, dan kemampuan untuk memunculkan berbagai jenis interaksi pembelajaran.

Pada pelaksanaan pembelajaran online ini, pesantren menggunakan aplikasi google classroom dan google meet yang terintegrasi ke smart-system pesantren. Selain itu, pembelajaran juga menggunakan media aplikasi whatsapp. Awalnya, smart-system mengurusi segala kebutuhan pengasuhan santri baik dari absen santri, rekap data kamar, prestasi, dan sebagainya. Namun, sejak ada pandemi Covid-19 ini yang mengharuskan melakukan pembelajaran jarak jauh, pesantren mulai memperbaiki diri dalam ranah pendidikan seperti denah kelas, wali kelas, rekap kelas santri, absen mengajar guru, dan memberikan fasilitas untuk ujian daring (online). Untuk mengakses media pembelajaran tersebut, baik guru ataupun santri harus mengunduh aplikasi google classroom, google meet, dan whatsapp serta dapat mengunjungi laman smartsystem pesantren, yaitu pada laman https://santri.darunnajah.com/ di laptop, tablet, telpon pintar (smartphone), dan komputer masing- 
masing. Tentunya, untuk dapat mengakases aplikasi tersebut, mereka harus juga memiliki akun atau registrasi terlebih dahulu. Dengan menggunakan aplikasi google classroom ini, guru membuat kelaskelas pembelajaran sesuai ampuannya. Setelah itu, guru memulai memasukkan materi dan tugas, mengundang santri, dan memantau perkembangan kegiatan pembelajaran.

Selama pembelajaran jarak jauh di rumah, santri tetap melakukan kegiatan seperti biasa ketika berada di pesantren. Mereka tetap menjalankan kegiatan keagamaan dan sekolah umum. Para santri memiliki jadwal kegiatan rutin yang dilaksanakan sejak pagi hingga malam, dari pukul 03.00 sampai 22.00. Adapun untuk pembelajaran daring sekolah umum dimulai dari pukul 07.30 sampai 11.15 melalui google classroom. Dalam hal ini, santri belajar secara mandiri dengan mempelajari materi yang diberikan guru di google classroom, tanpa tatap muka dengan guru. Terkadang, guru juga memberikan materi melalui google meet, meskipun memang tidak dilakukan setiap hari atau tidak ada jadwal secara khusus. Sebelum memulai pembelajaran, baik guru maupun santri harus mengisi kehadiran di smartsystem atau google classroom yang terintegrasi ke smartsystem. Hal ini dilakukan untuk melihat tingkat kehadiran dari guru dan santri tersebut.

Setiap hari, guru membuat materi/I'dad yang akan diunggah di google classroom sehingga bisa diakses oleh santri. Materi yang diberikan pun materi yang mudah dipahami dan dicerna oleh santri. Artinya, ketika mereka belajar mandiri pun tetap bisa memahami materi tersebut. Ketika pun ada santri yang tidak memahami, mereka dapat menghubungi teman atau guru. Tidak hanya berupa materi saja, tetapi guru juga membuat tugas atau latihan-latihan yang dapat digunakan santri untuk menambah nilai mereka. Materi yang diberikan pun beragam, hal ini sesuai dengan pernyataan santri bahwa materi dan tugas yang diberikan cukup beragam. Namun demikian, hampir tiap hari selalu diberikan tugas cukup banyak yang akhirnya membuat mereka kewalahan.

Dalam pembelajaran daring ini, santri hanya diberikan tugas-tugas mandiri saja, tidak ada tugas diskusi sehingga interaksi antarsantri pun tidak dapat terlihat. Tanya jawab antara santri dan guru hanya dilakukan ketika santri menanyakan secara pribadi kepada guru melalui whatsapp atau ketika guru sedang memberikan materi melalui google meet saja. Itu pun tidak dilakukan setiap hari. Dapat dikatakan bahwa interaksi yang terjadi masih terbatas satu arah, yaitu ketika guru memberikan materi atau tugas saja. Tugas yang diberikan setiap hari pun sebenarnya dapat menumbuhkan kemandirian kepada santri, di mana santri dapat mengerjakan tugasnya sendiri tanpa bergantung dengan jawaban dari orang lain. Hal ini sesuai dengan pernyataan Kuo, Walker, Schroder, dan Belland (2014) bahwa pembelajaran daring lebih bersifat berpusat pada siswa yang menyebabkan mereka mampu memunculkan tanggung jawab dan otonomi dalam belajar (learning autuonomy).

Temuan lainnya menunjukkan bahwa pembelajaran daring ini cukup menarik meskipun memang awalnya sedikit kesulitan dalam mengoperasikan aplikasi google classroom, google meet, dan smartsystem karena merupakan hal yang baru bagi guru dan santri. Hal ini karena mereka terbiasa dengan sistem pembelajaran yang konvensional atau klasikal secara tatap muka dalam melakukan pembelajaran. Meskipun hal yang baru dan belum terbiasa dengan pembelajarn daring ini, ada hal 
positif yang dapat diambil. Dalam hal ini, dengan pebelajaran daring ini, santri juga mengatakan bahwa mereka lebih bebas dan berani bertanya kepada guru tanpa malu atau takut diejek oleh temantemannya karena dilakukan secara privat. Selain itu, pembelajarannya tidak tegang seperti ketika di kelas dan lebih fleksibel dalam artian dapat mengikuti pelajaran di mana saja. Hal ini sesuai dengan prinsip pembelajaran jauh, prinsip keluwesan, mobilitas, dan efisiensi (Munir, 2012).

Untuk jam lainnya digunakan santri untuk melakukan kegiatan keagamaan seperti yang dilakukan selama di pesantren, misalnya shalat berjamaah, tilawah/membaca Al Qur'an, menghapal Ibadah Amaliyah, serta melakukan kegiatan lain seperti olah raga. Padamemakai sistem pembelajaran online, semua kegiatan pun dilaporkan secara daring. Misalnya, kegiatan keagamaan yang dilakukan oleh santri seperti menyetorkan laporan ibadah amaliyah, shalat berjamaah, tugas menyalin tulisan surat Al-Qur'an, dan tugas merangkum disampaikan santri kepada guru maupun wali kamar melalui whatssapp. Tidak hanya itu saja, santri di kelas tahfidz juga berlaku demikian. Mereka menyetorkan hapalan Al Quran melalui video whatssapp yang menurut mereka ini menjadi salah satu hal yang menyulitkan. Hal ini karena pengucapannya tidak terlalu terdengar atau terlihat berbeda ketika mereka mereka melaporkan hapalan secara tatap muka seperti di pesantren.

Dalam pembelajaran daring ini pun, orang tua juga ikut terlibat dalam mendukung anak mereka atau santri dalam belajar, meskipun tidak setiap hari. Bentuk dukungannya antara lain orang tua memantau anaknya dalam belajar, mengingatkan anak untuk belajar dan mengerjakan tugas, mengingatkan anaknya menjalankan kegiatan tugas kepesantrenan lainnya, serta terkadang menemani dan membantu anak belajar. Mereka juga terkadang membantu melakukan ceklis kegiatan selama santri di rumah dan mengirimkannya ke wali kamar/wali kelas di pesantren. Meskipun memang tidak setiap hari, sebisa mungkin mereka menemani atau mengingatkan santri atau anaknya untuk belajar.

Meskipun pembelajaran daring ini cukup menarik bagi santri dan guru, mereka lebih memilih pembelajaran tatap muka yang konvensional dibanding dengan pembelajaran daring. Hal ini karena materi akan lebih terserap jika dilakukan secara tatap muka, ada interaksi antara guru dengan santri secara langsung tanpa perantara media dan lebih mudah bertanya dengan teman dan guru secara langsung.

\section{Tantangan Pembelajaran Jarak Jauh}

Karena pembelajaran jarak jauh menggunakan model daring maka yang menjadi tantangannya adalah selain masalah jaringan yang kurang stabil, juga masalah kuota atau paket data yang mahal dan cepat habis. Santri menyatakan bahwa mereka sering kali terkendala jaringan yang timbul tenggelam sehingga menghambat pembelajaran daring dan susah mengunggah tugas. Apalagi jika guru menginginkan pembelajaran menggunakan google meet, pembelajarannya pun tidak maksimal karena suara terputus-putus. Namun, kondisi ini tidak hanya dirasakan oleh santri saja, guru pun sering kali terkendala jaringan sehingga terkadang tidak memungkinkan untuk melaksanakan pembelajaran menggunakan google meet. Kuota yang cepat habis dan cukup mahal juga menjadi kendala dalam pembelajaran daring ini. Misalnya, guru meminta pembelajaran menggunakan google 
meet dalam sehari ada dua pelajaran maka paket data atau kuota ini akan cepat habis akibatnya santri tidak bisa mengikuti pelajaran tersebut. Oleh karena itu, santri pun harus mengeluarkan uang atau biaya lebih untuk membeli paket data/kuota internet ini. Ditambah lagi belum adanya bantuan kuota internet yang mereka terima.

Tantangan lain pembelajaran jarak jauh ini adalah santri kurang berpartisipasi aktif dalam kegiatan pembelajaran. Hal ini karena tidak adanya bertatapan langsung dengan gurunya sehingga santri merasa lebih bebas, apalagi pembelajaran hanya dilakukan menggunakan google classroom yang tidak ada pengawasan khusus dan kurangnya motivasi dari santri tersebut dalam mengikuti kegiatan pembelajaran. Tingkat partisipasi santri hanya dilihat dari absensi yang masuk dalam google classroom dan form kegiatan yang dikirimkan melalui whatsapp, itu pun bisa dimanipulasi oleh santri. Kurangnya pertemuan menggunakan google meet juga menjadi kendala dalam pembelajaran. Hal ini juga menyebabkan interaksi antara santri dengan guru menjadi lebih berkurang. Dapat dikatakan bahwa keterpisahan fisik dapat memengaruhi interaksi antara guru dan santri. Seperti yang dikatakan Moore (Belawati, 2019) bahwa keterpisahan dalam pembelajaran jarak jauh sebenarnya tidak hanya berupa keterpisahan secara geografis dan waktu, namun juga ada keterpisahan secara psikologis dan komunikasi. Keterpisahan ini menciptakan ruang untuk terjadinya miskomunikasi karena guru tidak bisa memberikan penilaian langsung ataupun santri tidak bias bertanya secara langsung atas materi yang dipelajari. Selain itu, tugas yang terlalu banyak dan kurangnya kegiatan diskusi juga menjadi tantangan tersendiri dalam pembelajaran ini. Apalagi diskusi ini sebenarnya penting untuk dilakukan karena dapat digunakan untuk melihat dan menilai keaktifan santri.

\section{Culture Shock}

Dengan adanya pandemi Covid-19, salah satu dampaknya adalah munculnya gegar budaya (culture shock) yang dialami oleh masyarakat pada umumnya, maupun masyarakat sekolah. Gegar budaya ini juga muncul di dunia pendidikan yaitu dialami oleh para guru, santri, dan orang tua santri di Pondok Pesantren Darunnajah 2 Bogor. Gegar budaya dapat diartikan sebagai keadaan seseorang tidak mengenal kebiasaan sosial dari budaya baru sehingga ia tidak dapat menampilkan perilaku yang sesuai dengan aturan di lingkungan baru tersebut (Dayakisni \& Yuniardi, 2017). Culture shock dimulai dari diberlakukannya pembelajaran jarak jauh oleh pesantren. Dalam pembelajaran, guru dan santri mengalami kebingungan dalam menggunakan aplikasi penunjang pembelajaran, yaitu menggunakan google classroom. google meet, dan smartsystem. Apalagi, mereka terbiasa dengan pembelajaran yang tatap muka dan melakukan berbagai kegiatan kepesantrenan di asrama. Tentunya, baik guru, santri, dan orang tua merasa khawatir dengan pembelajaran jarak jauh tersebut.

Awalnya, mereka belum terlalu mengenal aplikasi tersebut meskipun hampir setiap hari mereka menggunakan telepon pintar (smartphone), tetapi dengan adanya pembelajaran jarak jauh ini, baik guru dan santri mau tidak mau membiasakan diri menggunakan aplikasi tersebut. Kebingungan pun bertambah ketika ternyata pesantren kurang dalam memberikan sosialisasi penggunaan aplikasi tersebut. Sosialisasi hanya dilakukan oleh wali kelas melalui whatsapp, bukan dari sosialisasi secara 
umum dari pesantren misalnya dengan pemberian video tutorial. Kurangnya sosialisasi ini juga dapat memicu tidak efektifnya proses pembelajaran secara jarak jauh. Selain itu, dengan dilakukannya pembelajaran jarak jauh menggunakan sistem online ini, memunculkan kekhawatiran jika pembelajaran tidak akan berjalan dengan efektif sehingga hasil kegiatan pembelajaran pun tidak akan maksimal, takut jika nilai yang diperoleh jelek dan tidak memuaskan, dan sebagainya. Santri pun mengkhawatirkan bahwa takutnya mereka akan stres dan kewalahan karena beban tugas semakin banyak yang diberikan guru setiap hari. Hal ini seperti apa yang dikatakan Lubis (2015) bahwa gegar budaya dapat terjadi akibat kesenjangan antara budaya lama dengan budaya baru yang dialami oleh individu dan menyebabkan kebingungan, kemudian menimbulkan pemikiran negatif terhadap keadaan baru.

\section{Physical Distancing}

Pembelajaran jarak jauh tidak berlangsung dalam suatu ruangan kelas sehingga tidak ada interaksi langsung secara tatap muka antara pengajar dan pembelajarnya merupakan bagian dari satu cara physical distancing. Hal ini sesuai dengan imbauan dari WHO dan pemerintah melalui Kemendikbud bahwa baik pengajar maupun siswa melakukan kegiatan belajar mengajar dari rumah. Pembelajaran jauh jauh yang dilakukan oleh Pondok Pesantren Darunnajah 2 Bogor juga menjadi salah satu cara physical distancing demi memutus penyebaran virus tersebut. Apalagi pesantren merupakan sekolah berasrama yang hampir setiap saat santri intens bertemu melakukan kegiatan keagamaan, keasramaan, dan kegiatan belajar bersama. Proses pertemuan yang sangat intens antarsantri dan guru di asrama menjadi kekhawatiran tersendiri. Dengan melakukakn physical distancing, kebiasaan yang dilakukan di pesantren tidak bisa dilakukan sehingga cara ini cukup efektif untuk mencegah penyebaran virus. Dalam kegiatan pembelajaran, dengan adanya physical distancing ini, interaksi antarsantri maupun antara santri dengan guru hanya bisa dilakukan dengan menggunakan media, seperti google meet, whatsapp, atau media sosial lainnya. Tidak ada lagi tanya jawab secara spontan dari guru maupun santri serta tidak ada kerja sama yang dapat dilakukan. Meskipun demikian, pada intinya mereka tetap dapat melakukan hubungan sosial meskipun memang terkendala jarak dan harus menggunakan media.

\section{Kesimpulan}

Sebagai upaya untuk memutus penyebaran virus Covid-19 di lingkungan pesantren, pembelajaran jarak jauh menggunakan sistem daring menjadi salah satu solusi. Berdasarkan penelitian dapat diketahui bahwa dalam pembelajaran, pesantren menggunakan berbagai platform seperti google classroom, google meet, whatsapp, dan smart system. Dalam pembelajaran daring ini, materi dan tugas yang diberikan cukup beragam, meskipun tidak ada tugas dalam bentuk diskusi sehingga interaksi antara santri dengan santri maupun santri dengan guru tidak dapat dilakukan. Semua pihak, baik santri, guru, maupun orang tua mengalami gegar budaya (culture shock) dengan adanya sistem pembelajaran jarak jauh/daring ini. Mereka belum terbiasa dengan sistem pembelajaran ini, meskipun 
mereka sudah terbiasa menggunakan teknologi seperti telepon pintar dan internet. Pembelajaran jarak jauh/daring juga memunculkan adanya menjaga jarak fisik (physical distancing). Kegiatan keagamaan yang biasanya dilakukan di pesantren pun kini dilakukan di rumah dan semuanya harus dilaporkan kepada guru atau wali kamar melalui whatsapp. Tantangan yang dihadapi dalam pembelajaran daring ini antara lain kurangnya interaksi antara guru dan santri, jaringan yang timbul tenggelam, kuota yang cepat habis dan mahal, dan kurangnya partisipasi aktif santri. Oleh karena itu, diperlukan kesiapan baik guru dan santri, serta motivasi dari orang tua juga dapat mendukung terlaksananya proses pembelajaran jarak jauh ini. Selain itu, pemberian kuota juga menjadi hal yang penting untuk mendukung proses pembelajaran daring yang dilakukan pesantren.

\section{Daftar Pustaka}

Belawati, Tian. 2019. PembelajaranOnline. Tangerang Selatan: Universitas Terbuka.

Creswell, John W (2016). Pendekatan Metode Kualitatif, Kuantitatif, dan Campuran. Yogyakarta: Pustaka Pelajar.

Dayakisni, T., \& Yuniardi, S. (2017). Psikologi Lintas Budaya (Edisi Revisi). Malang: UMMPress.

Direktorat Jenderal Guru dan Tenaga Kependidikan, Kementerian Pendidikan dan Kebudayaan. 2020. Panduan Pembelajaran Jarak Jauh.

Kemendikbud. 2020. Surat Edaran Nomor 4 Tahun 2020 tentang Pelaksanaan Kebijakan Pendidikan dalam Masa Darurat Penyebaran Covid-19.

Korucu, A. T., \& Alkan, A. (2011). Differences between m-learning (mobile learning) and elearning, basic terminology and usage of m-learning in education. Procedia-Social and Behavioral Science from https://doi.org/10.1016/j.sbspro.2011.04.029

Kuo, Y. C., Walker, A. E., Schroder, K. E. E., \& Belland, B. R. (2014). Interaction ,Internet selfefficacy, and self-regulated learning as predictors of studentsatisfaction in online education courses. Internet and HigherEducation. https://doi.org/10.1016/jiheduc.2013.10.001

Lubis, R. (2015). Sosiologi Agama: Memahami Perkembangan Agama dalam InteraksiSosial. Jakarta, Indonesia: Kencana.

Maizan, Sabrina Hasyyati., Khoiruddin Bashori, dan Elli Nur Hayati. 2020. AnalyticalTheory: Gegar Budaya (CultureShock). PSYCHO IDEA, Tahun 18. No.2, Agustus 2020. http://jurnalnasional.ump.ac.id/index.php/PSYCHOIDEA/article/view/6566/3347

Moleong, Lexi J (2011). MetodePenelitianKualitatif. Bandung: Remaja Rosdakarya.

Moore, J. L., Dickson-Deane, C., \& Galyen, K. (2011). E-Learning, online learning, and distance learning environments: Are they the same? Internet and Higher Education. https://doi.org/10.1016/j.iheduc.2010.10.001

Munir.2012. Pembelajaran Jarak Jauh Berbasis Teknologi dan Komunikasi. Bandung: Penerbit Alfabetha.

Public Health Ontario. (2020). Coronavirus Disease 2019 (COVID-19): Physical Distancing. Retrieved from https:/www.publichealthontario.ca//media/documents/ncov/factsheet/factsheet-covid-19-guide-physicaldistancing.pdf?la=en

Sugiyono. 2011.Memahami Penelitian Kualitatif. Bandung: Alfabeta.

WHO. 2020. Coronaviruse Disease (COVID-19) Advice for Public. World Health Organization. 